\title{
DEFENSIVE CHURCH OF SAINT NICHOLAS AND THE MONASTERY OF BERNARDINS IN BEREZHANY
}

\author{
ОБОРОННИЙ КОСТЕЛ СВЯТОГО МИКОЛАЯ \\ ТА МОНАСТИР ОО. БЕРНАРДИНІВ У БЕРЕЖАНАХ
}

(C) Тихий Б., 2020.

Анотація: За переказами на горі Святого Миколая, на місці теперішнього монастиря був боярський двір, потім церква Святого Миколая. У 1630-1742 рр. повстав оборонний комплекс монастирських споруд - костелу Святого Миколая та монастиря оо. Бернардинів, щзо мав статус найвищої і найбільшої стратегічної точки на теренах північно-західної оборонної системи м. Бережани, адже контролював дорогу ЛьвівБережани. Спорудження його корпусів тривало 112 років.В 1809-1812 рр. австрійська влада ліквідувала потужні оборонні вали міста, в тому числі й бастіони на території монастиря. На щастя, на південному схилі гори залишився фрагмент оборонного валу $і$ рову, який зафіксований на фото $і$ вказаний на мапі 1720 р. майора Йогана фон Фюрстенгофа.В статті згадано про підземні ходи та віднайдені у 2010 р. настінні фрески. Висунуті здогадки авторства рідкісної конфігурації капітель та колон роботи Іоана Пфістера (в 1630-1642 рр.), та вівтарів, з різьбленими фігурами святих - роботи мистця Георга Іоана Пінзеля з Бучача.Описано сучасний стан монастиря $і$ мощі новітніх мучеників, але не в повному об'ємі розкрита тема саме оборонного монастиря.Цікаво, що в храмі знаходяться кілька ікон з пророчого ряду відомого краснопущанського іконостасу роботи Гната Стобинського і о. Теодозія Січинського, який у 1912 р. подарував митрополит Андрей Шептицький.В 2007 р. старовинний монастир відвідав Президент Украӥни Віктор Ющенко $і$ допоміг будівельними матеріалами, виділивши деревину ( 54 м. куб. дуба) на перекриття покрівлі храму.

Ключеві слова: костел Святого Миколая, монастир оо. Бернардинів, Синявські, підземелля, підземні ходи, оборонна система, бастіони, Пратулинські мученики, Антоній Падевський, чудотворна Фрагська Божса Матір, мощі.

У 1630 році на горі Святого Миколая, в північно-західному наріжнику Бережан, шляхтич Микола Синявський (1598-1636) разом зі своєю дружиною Урсулою Софією Синявською (пом. 1637) розпочав будівництво костелу та споруд майбутнього монастиря (Maciszewski, 1910, s. 112; Ostrowski red., 2007, s. 127). Однак смерть Миколи Синявського та його дружини, а також народні повстання, на десятки років перервали це будівництво, початок другого етапу якого затягнувся аж до 1683 року (Maciszewski, 1910, s.112). Утім, 
вже в 1681 році першим ігуменом до недобудованого монастиря прислано о. Антонія Фредро (Maciszewski, 1910, s.114).21 липня 1683 р. гетьман польний коронний Микола Сронім Синявський в актах «гродських» львівських підтверджує наміри закінчити будівництво костелу Святого Миколая та монастиря оо. Бернардинів, зазначивши, що саме вони були сповідниками і наставниками його предків (Maciszewski, 1910, s.112).

На утримання костелу і кляштору фундатор призначив десятий сніп 3 фільварків Нараєва, Саранчук, Вільхівця, а з інших маєтків бережанського ключа 550 п. зол. Окрім того, велів щорічно на утримання монастиря давати 6 ялівок, 4 свині, 10 баранів, 2 бочки меду, бочку соленої риби, 3 камені воску і 5 каменів волового лою. На додаток до цих доходів Синявський подарував монастирю фільварок з городом, садом, частину ріки та сажівку і зобов'язав всіх своїх спадкоємців до реставрації монастиря в міру такої необхідності. Також побажав, щоб призначили для нагляду отця, що добре орієнтується в будівельних та господарських справах (Maciszewski, 1910, s.113).

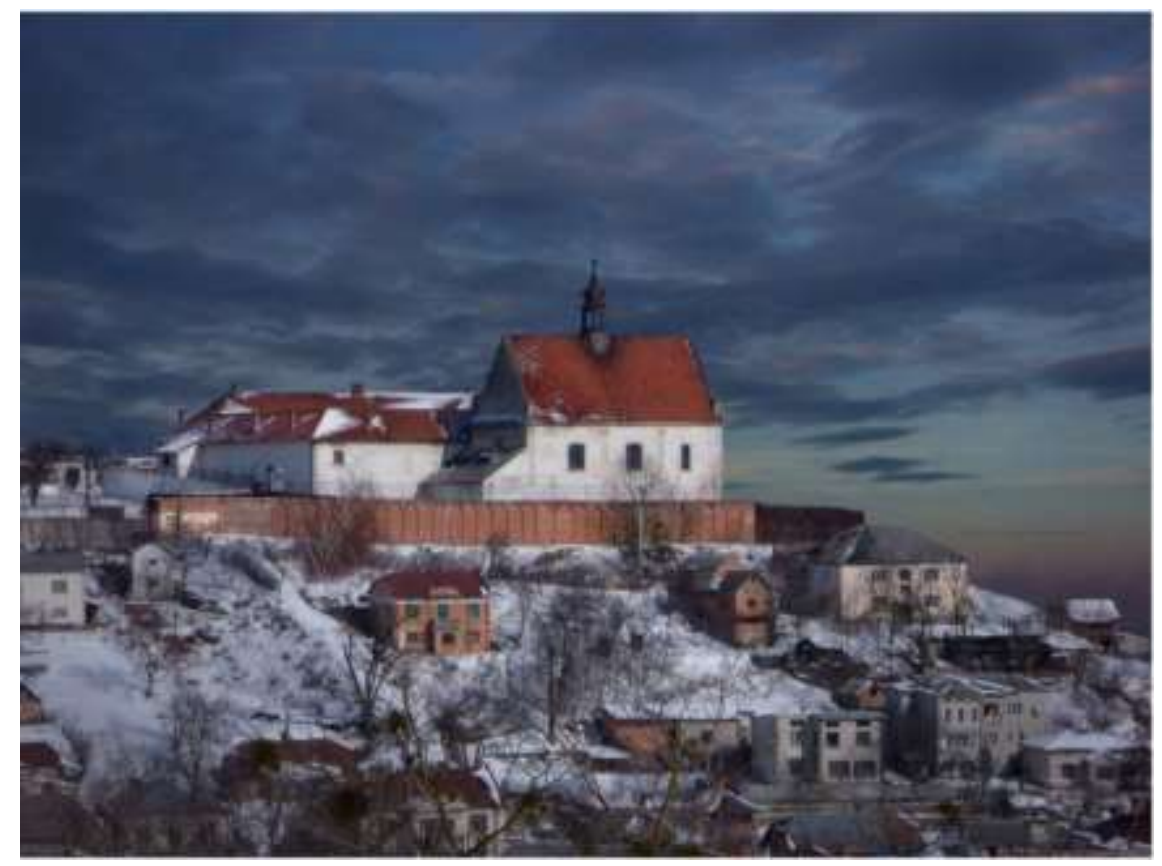

Рис. 1. Вид на оборонний монастир оо. Бернардинів.

Фото О. Шупляка, 2005 р. Зліва, на схилі гори, фрагмент залишків оборонного валу та рову міста.
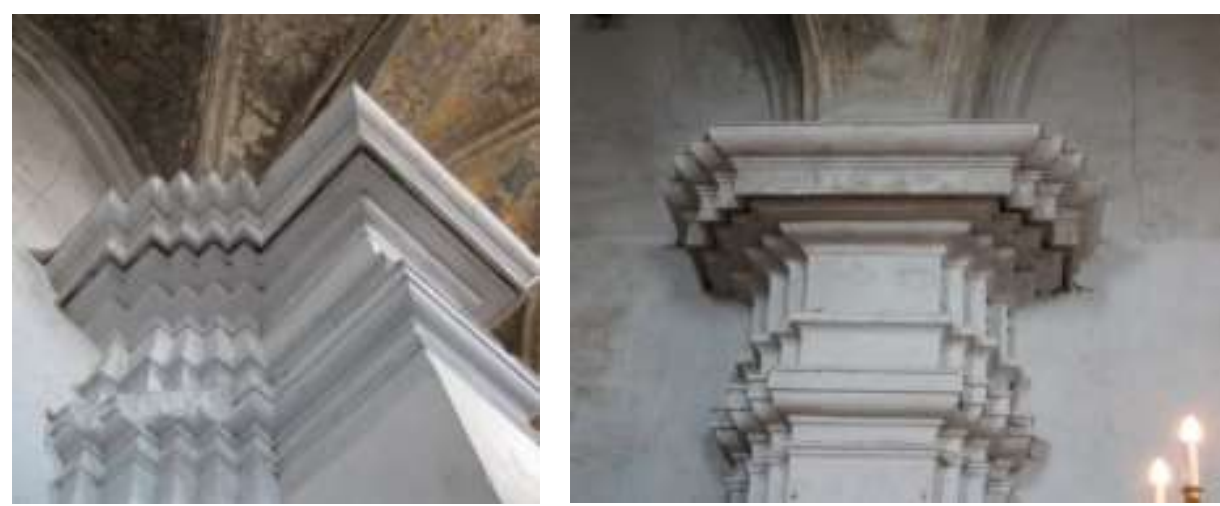

Рис. 2. Ажурні капітелі костелу, ймовірно, роботи майстерні Іоана Пфістера в період будівнищтва храму з 1630-х рр. Фото автора, 2010 р.

Синявський наказав жителям, які мають сильних волів і міцні вози, взимку 1683 року завезти на круту гору будівельні матеріали і камінь для продовження будівництва монастиря. Наказ гетьмана був виконаний. Однак під час бою з турками під Віднем сам Микола Сронім 
Синявський отримав важкі рани і невдовзі, у січні 1684 р., помер (Maciszewski, 1910, s.114). Після смерті воєводи фундування будівництва продовжив його син Адам Микола Синявський, гетьман великий коронний, каштелян краківський. Однак активну добудову монастиря розпочато аж 23 вересня 1716 року. Того ж дня, львівський архієпископ Ян Скарбек (1713-1733) освятив костел. Але урочисте впровадження отців до кляштору відбулось ще пізніше - 8 серпня 1720 р. за участю архієпископа Яна Скарбека, що побував у Бережанах з канонічною візитацією. У 1724 р. добудовано ганки, сходи костелу і довершено внутрішню галерею, територію монастиря обведено муром. А в 1730 р. замінено дах костелу (Maciszewski, 1910, s.114). Отож, будова костелу і монастиря тривала 112 років. Спорудження, власне, монастиря завершено аж у 1742 році стараннями Софії Марії Чарторийської з Синявських (Ostrowski red., 2007, s. 128-129).

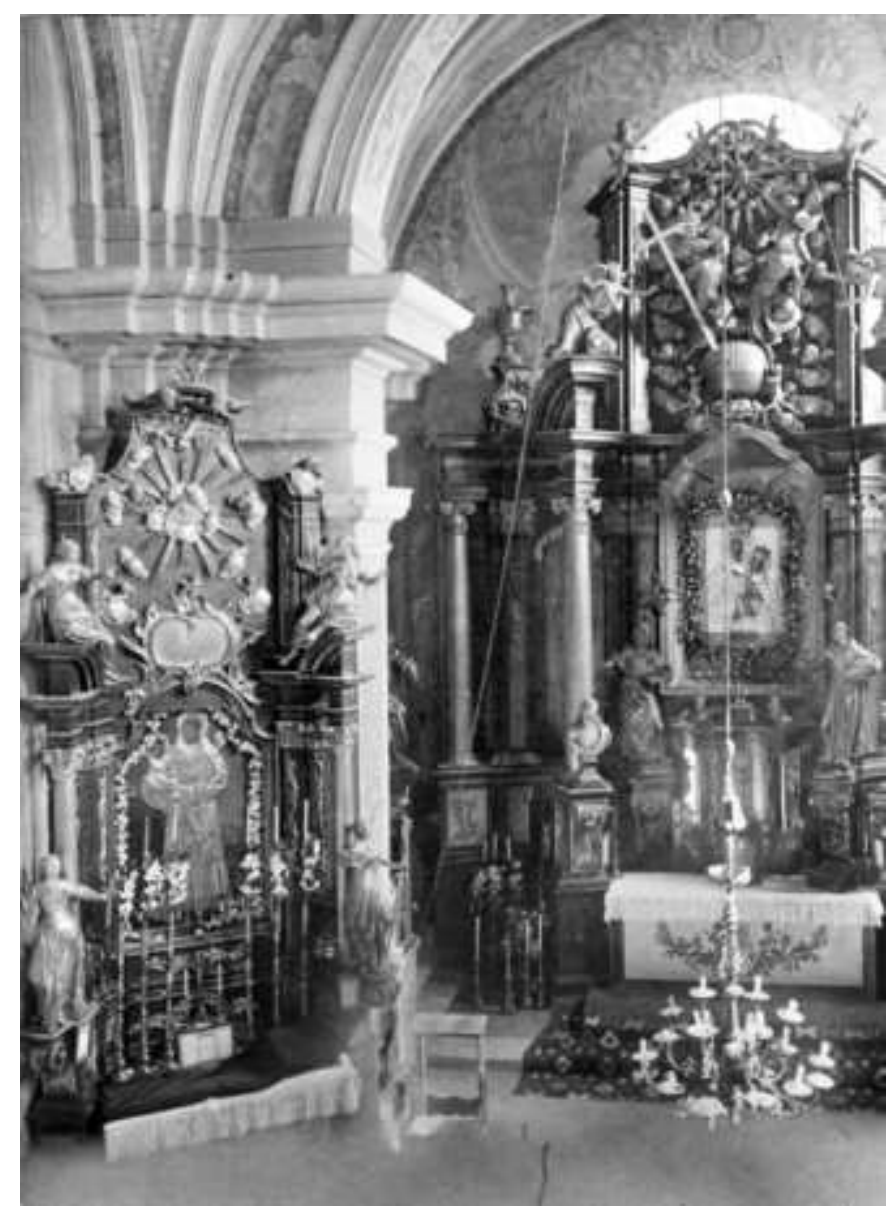

Рис. 3. Центральний та боковий вівтарі з чудотворними образами - Матері Божої Фрагської (XVII cm.) й св. Антонія Падевського (XVIII cm.), роботи Георга Іоана Пінзеля, придворного мистия Стефана

Потоиького та його дружини Іоанни з Синявських, тітки Софії Марії Чарторийської з Синявських.

Костел мав три вівтарі: центральний - успіння Пресвятої Діви Марії, зліва - св. Антонія, справа - св. Миколая. У 1808 р. у головний вівтар вміщено чудотворний образ Матері Божої, привезений з монастиря оо. Бернардинів у с. Фрага (Рогатинщина), який, зрештою, 14 серпня 1904 року, після відновлення монастиря і каплиці у Фразі, був туди урочисто повернутий (Слободян, 2004, с.208). Вівтар зліва - на честь покровителя (патрона) Бережан св. Антонія Падевського. Його образ перебував у монастирі з 13 червня 1717 p. i прославився чудами оздоровлення. Зараз він знаходиться в костелі Матері Божої Фатімської в Лодзі (Польша). Третій вівтар костела Святого Миколая, з правого боку, був присвячений фундаторові Миколі Сроніму Синявському. У вівтарі домінував великий образ св. Миколая. 
У 1785 році представники австрійської влади здерли срібні оздоби з образів св. Миколая (оклад) та св. Антонія (ореол та пасок) та конфіскували срібні прикраси, три срібні келихи, хрест з ланцюжком, три срібні яблука та багато дорогоцінних предметів (Maciszewski, 1910, s.114).

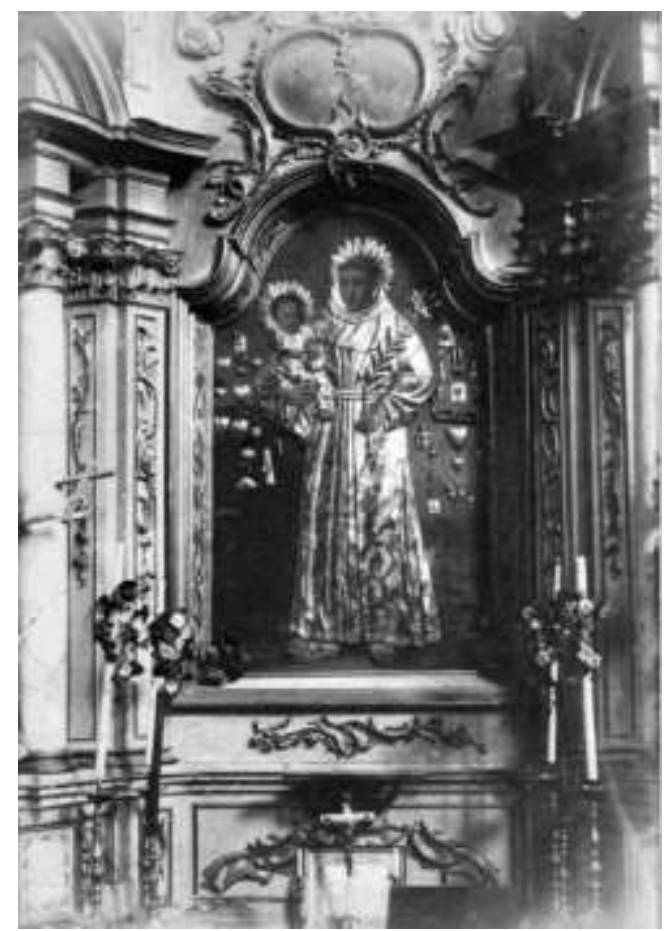

Рис. 4. Образ св. Антонія з дитятком у срібному окладі.

У 1824-1825 pp. монастир оновлено коштом графа Потоцького. Сума видатків становила 5094 зл. Роботами керував уповноважений Потоцьким інженер. Однак були й спірні ситуації між кляштором в особі о. Філіновського і виконавцями робіт щодо заміни кам'яної підлоги на дерев'яну та будівництва пивоварні (Maciszewski, 1910, s.113).
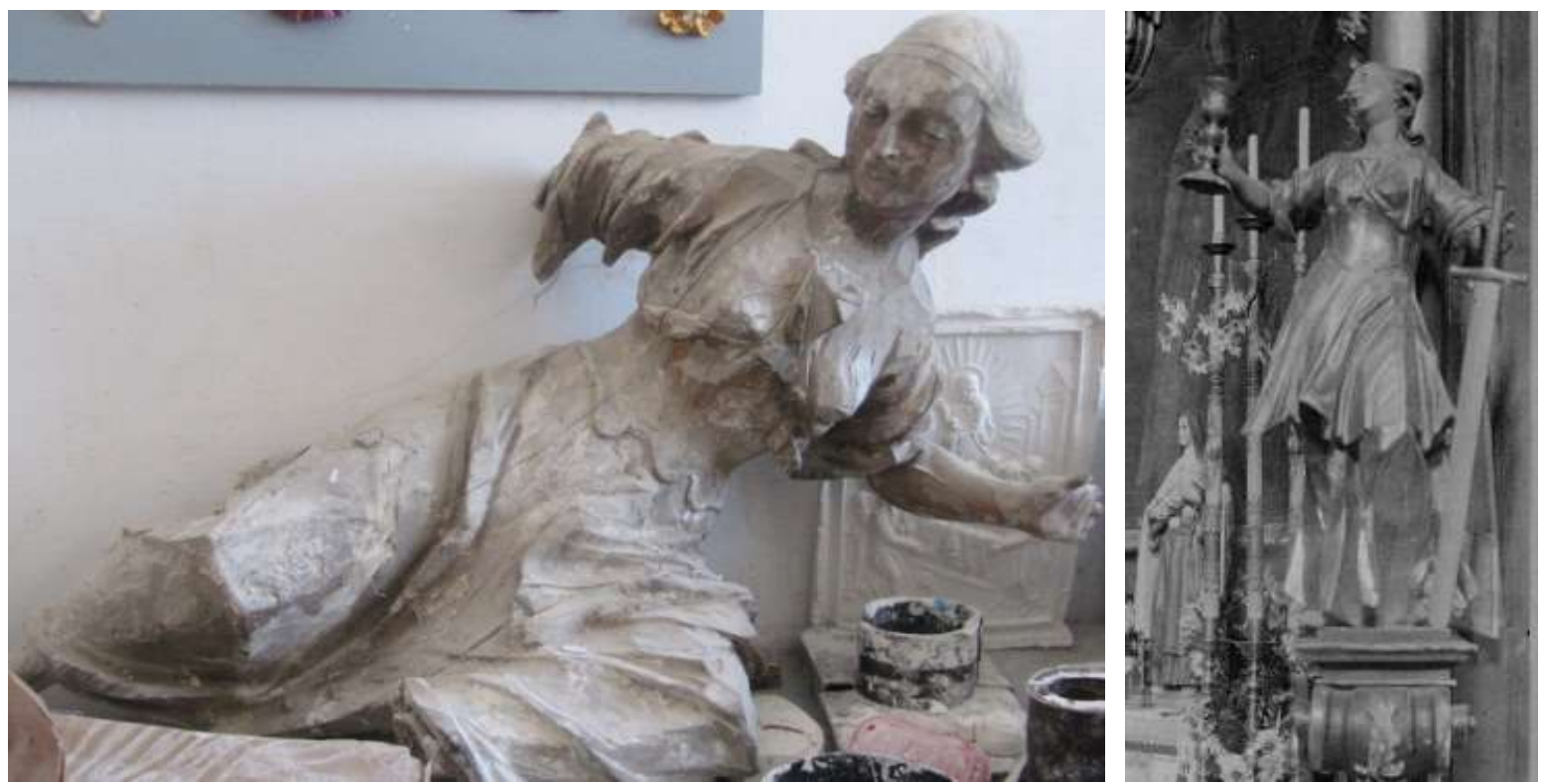

Рис. 5. Збережений фрагмент деревяної скульптури з вівтаря костелу. Фото автора 2015 p. 


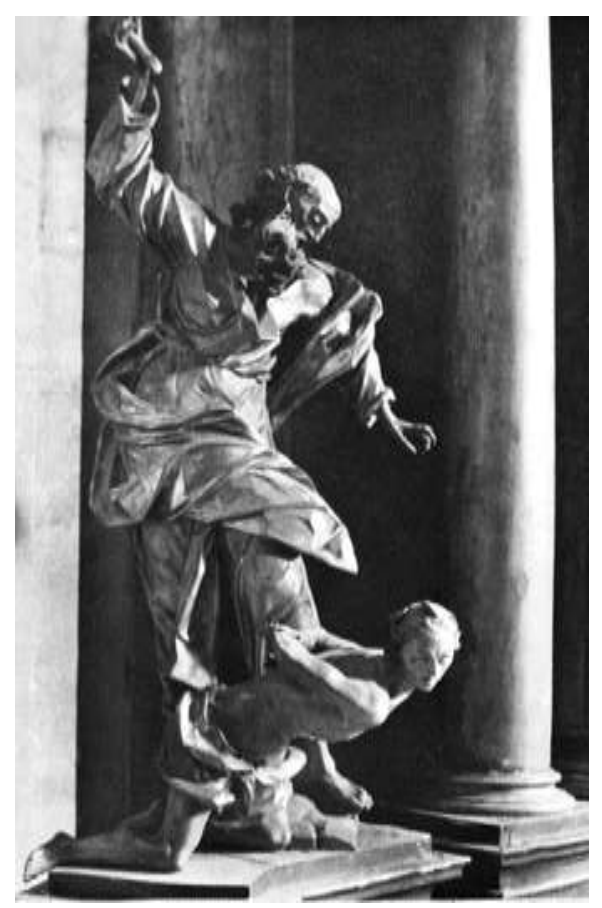

Рис. 6. Втрачена робота Іоана Георга Пінзеля.

Обвідний мур реконструйовано й відновлено в 1906 р. як і фігуру св. Антонія. У 1930y, після руйнацій, нанесених Першою світовою війною, монастир відреставровано (Wojewodstwo Tarnopołskie, 1931, s.441). На південній зовнішній стіні костела, зі сторони міста, видно великий сонячний годинник (див. рис. 19). Поряд з храмом була триаркова дзвіниця з трьома дзвонами. Щороку проводилось два великі відпусти: 13 червня, з нагоди патрона міста св. Антонія, та 15 серпня, в день Успіння Пресвятої Богородиці. До речі, в монастирі стояв також вівтар з фігурою Богородиці з Дитям Ісусом на руках. Називали фігуру «Чорною Мадонною», з огляду на колір обличчя, бо фігура в натуральну величину була дерев'яною. Походила вона, мабуть, з кінця XVIII або початку XIX ст. Поряд 3 гостинною кімнатою і трапезною знаходилась бібліотека. Справа біля великого престолу розміщувались три надгробні таблиці 3 написом: Томаш Журовський, стольник жидачівський, рицар-гусар, Маріана з Укдорфів Журовська, стольникова жидачівська; Адам Нісіловський з старовинного роду Коржбоків пом. 13 квітня 1774 р. У підземеллі спочивають перший монастирський ігумен о. Антоній Фредро та ще п’ять осіб - Олена та Войцех Ревуцькі, Катерина Бобровська, Анна Забельська та Анна Марія де Ласнер. Решту підземелля займають труни померлих отців і братії монастиря (Maciszewski, 1910, s.114; Steiner, «Glos Brzezanski» № 8, 1934, s.3-4). Найціннішою є третя таблиця - $з$ написом про капітана Адама Нісіловського, військового архітектора, який був поручником царського ескорту московського царя Петра I і відзначився в багатьох битвах проти шведів. Всі пам’ятні таблиці встановлені в кінці XVIII ст.

У приміщенні поруч захрестія стояли дубові шафи, де зберігалися золоті і срібні чаші, гаптовані золотом і сріблом фелони, золота скринька, срібна монстрація. Гаптований перлами фелон був подарунком короля Яна III Собеського. 


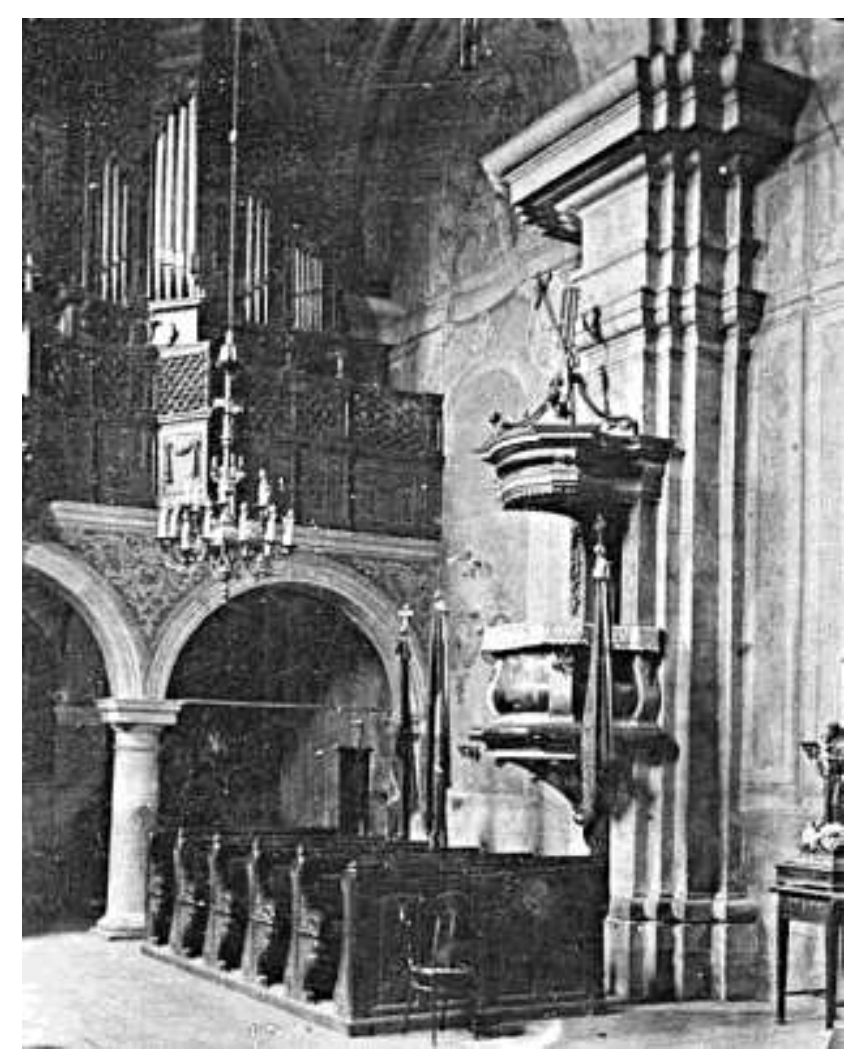

Рис. 7. Хори та орган костелу Святого Миколая.

У монастирі висіли два портрети: Миколи Єроніма - в гостинній залі, та в костелі Адама Миколи Синявського, в повний зріст з підписом латинською мовою. На суфіті костелу - спарені герби Синявських та Любомирських (Ostrowski, ed., 2007, s.134-139).

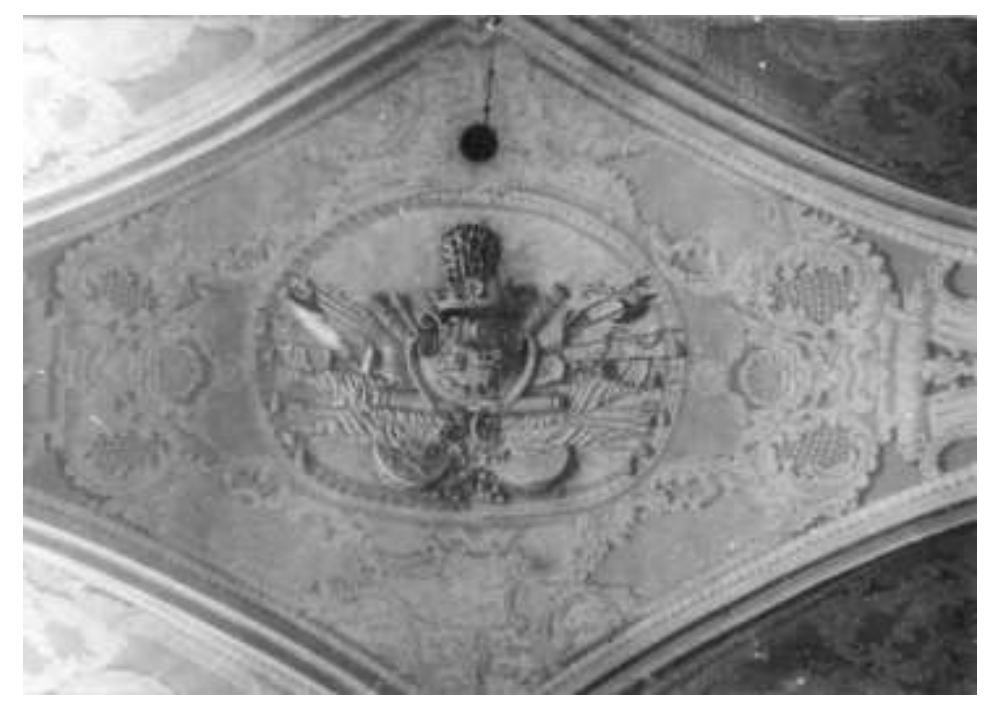

Рис. 8. Спарений гербовий щзит Синявських-Любомирських на суфіті костелу Святого Миколая.

Монастир мав велике оборонне значення, адже входив в оборонну систему міста в пінічно-західному іiі наріжнику і при необхідності контролював дорогу Львів-Бережани, підтримуючи вогнем артилерії бастіон під захистом якого була Львівська брама. Територія біля монастиря була досить потужнім оборонним вузлом, з висунутим до переду бастіоном. Наріжний бастіон мав, досить цікаву, корончасту форму. Міські укріплення базувались на засадах Староголландської школи бастіонової архітектури і являли собою вал з парканом і глибокий рів. Територія монастиря була обведена ще й автономним муром з стрільницями. 
(Бевз, 2000, с.14-15). Бастіон Львівської брами був з'єднаний таємним підземним переходом 3 наріжним бастіоном.

В 1809-1812 рр. міські вали було розібрано за наказом російської окупаційної влади та командування царського війська, що на той час окупувало Бережани.

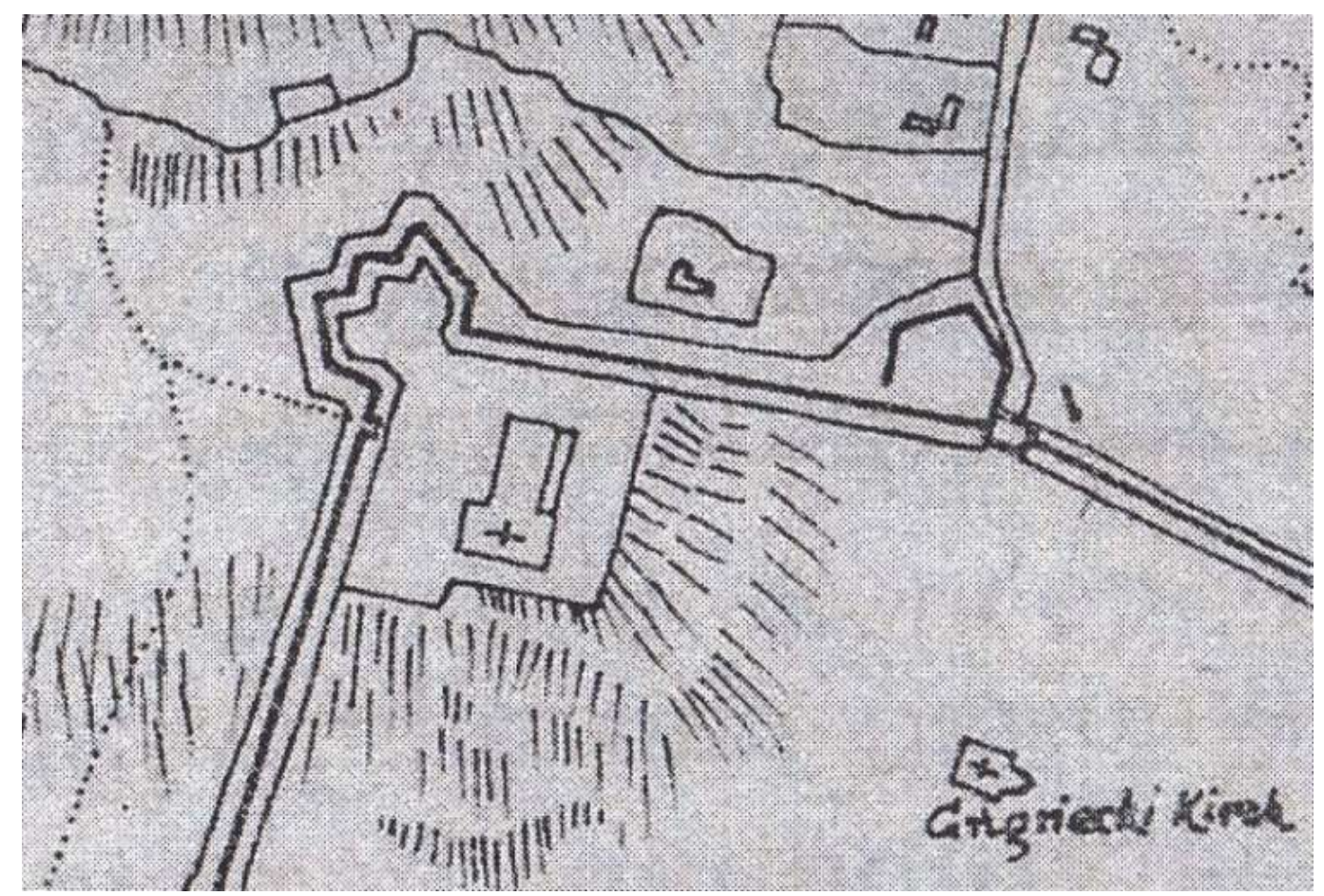

Рис.9. Оборонні вали монастиря і бастіон де розмімувались гармати.

Фрагмент копії 1905 р. В. Каліновського з мапи Бережан 1720 р.

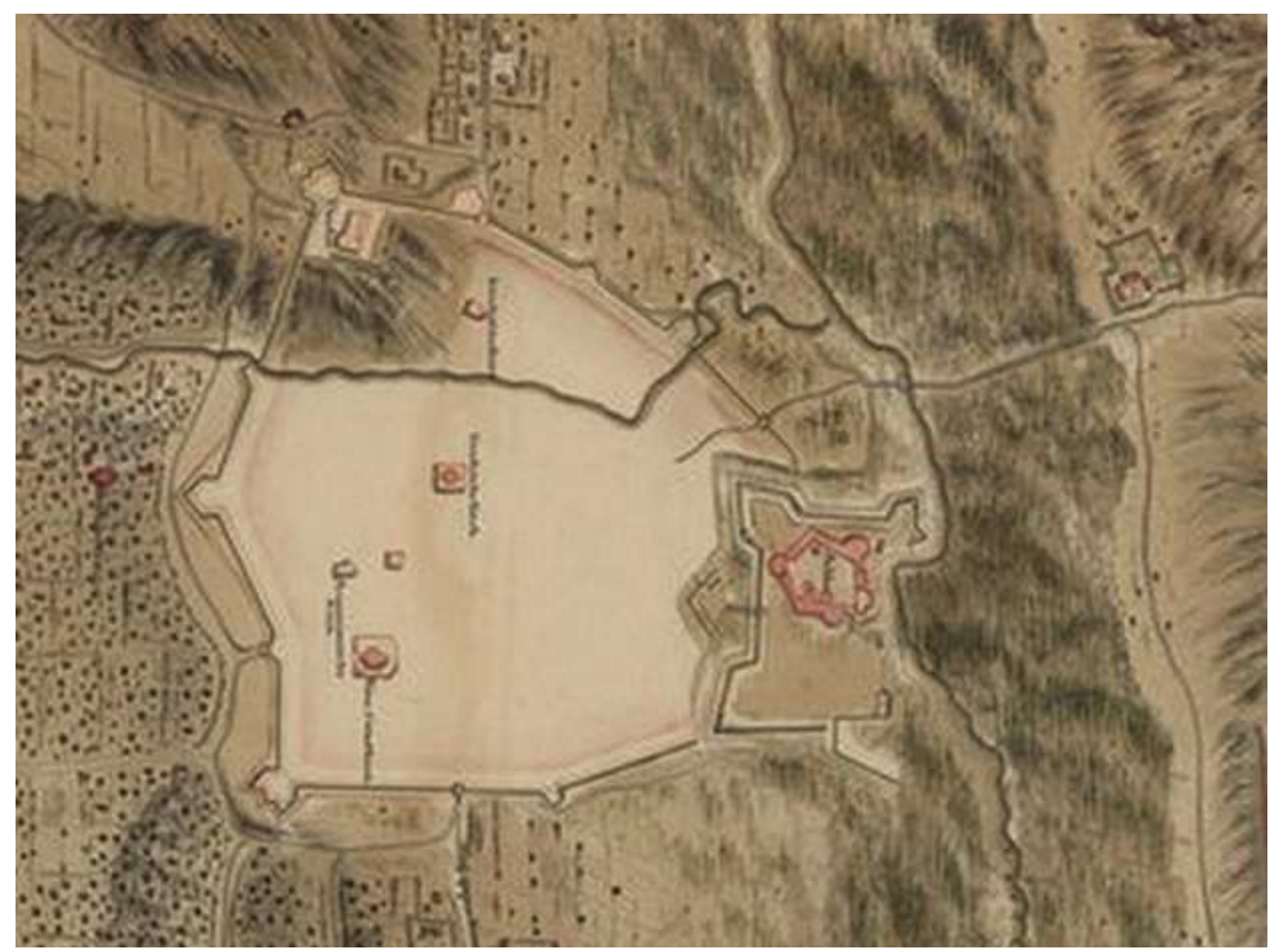

Рис.10. Мапа оборонної системи Бережан 1720 р. майора Йогана фон Фюрстенгофа (Fürstenhoff, 1755) 


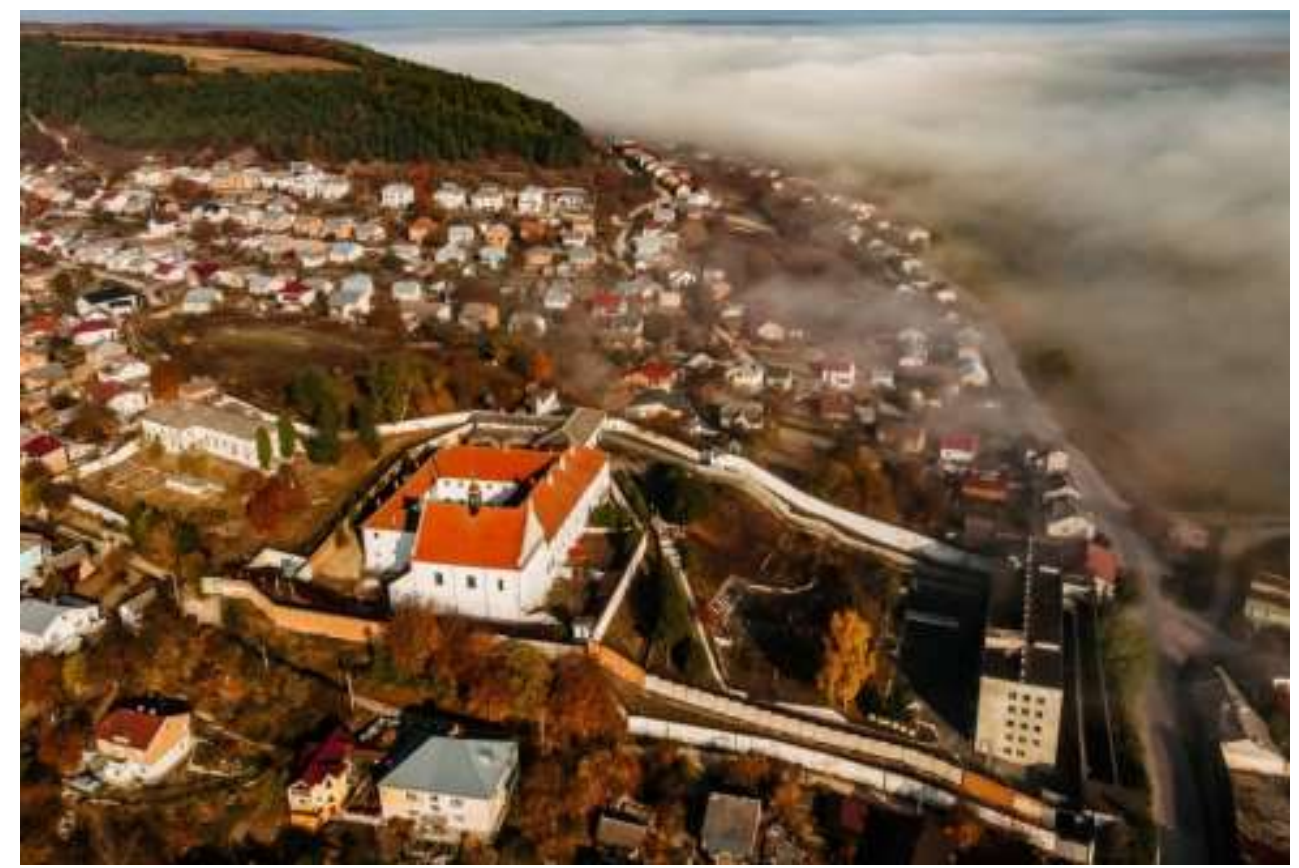

Рис. 11. Монастир з пташиного лету. Фото Олександра Наконечного, 2018 р.

У костелі три крипти. В одній з них зберігався портрет з підписом «Незабитовський Якуб, славний переможець та гроза татарів в XVI столітті» (Ostrowski, ed., 2007, s.134-139). Головний вхід до підземелля костелу був зі святилища, таємний - з внутрішнього дворика. Внизу, біля замурованих сходів перед головним вівтарем, є ніша, в яку 8 червня 1771 р. покладено і замуровано срібну чашу-пушку, запаяну в олов'яну капсулу, в якій нутрощі i серце Адама Миколи Синявського, як він і заповідав. Інший, таємний вхід до підземелля 3 внутрішнього дворика знайдений лише в 1964 році. Монастир мав підземні хіди до замку, костелу та середмістя. Тепер ходи місцями завалені, або забудовані будинками. Хроніка костелу оо. Бернардинів згадує про цвинтар при костелі та деякі імена похованих: Лукаша Гідзінського (пом. 05.01.1774), о. Амброзія Ласса (пом. 28.03.1775), Катерини Цабан (пом. 18.01.1782), о. Віта Саєцького (пом. 19.01.1794) та інш. Коли в 1927 році його обводили муром і клали нові сходи до монастиря і крипт костелу, збудованих ще в 1737 році, натрапили на дуже старі, вже спорохнявілі кості, які перепоховали неподалік дзвіниці (Ostrowski, ed., 2007, s.134-139).

У 1939 р., після відомих історичних подій, у частині приміщень розмістили дім перестарілих. У роки війни німці забрали два дзвони, а в 1943 р. монастир перетворили на військовий госпіталь. Монахи виїхали до Львова. На горі біля костелу Святого Миколая хоронили німецьких вояків. У липні 1944-го радянська влада познімала з могил на монашому цвинтарі хрести, а самі могили зрівняла із землею. У серпні 1945-го костел і монастир закрито, а ченці перебрались до Польщі, забравши з собою майже все майно. (Ostrowski, ed., 2007, s.134). Монастирські приміщення перетворено на своєрідну тюрму - виховну колонію для неповнолітніх.

\section{Церква Мучеників Пратулинських}

28 березня 2000 р. приміщення костелу Святого Миколая у жалюгідному стані офіційно передано греко-католицькій парафії, а у травні того ж року владика Тернопільської єпархії Михаїл Сабрига передав церкві антимис. Храм освячено іменем Мучеників Пратулинськиї. Утворену релігійну громаду УГКЦ Бережанської виправної колонії та прилеглих до території монастиря жителів міста, затвердив зборівський єпископ Михаїл Колтун. Першим парохом парафії від початку ії заснування до жовтня 2004 р. був о. Зеновій 
Афінець. Першу візитацію до храму, що відроджувався, здійснив владика Михаїл Колтун на Різдво 1999 р. Упродовж листопада 2004 р. настоятелем був о. Петро Половко, а з 9 грудня 2004 р. адміністратором парафії призначено капелана о. Михайла Бугая.

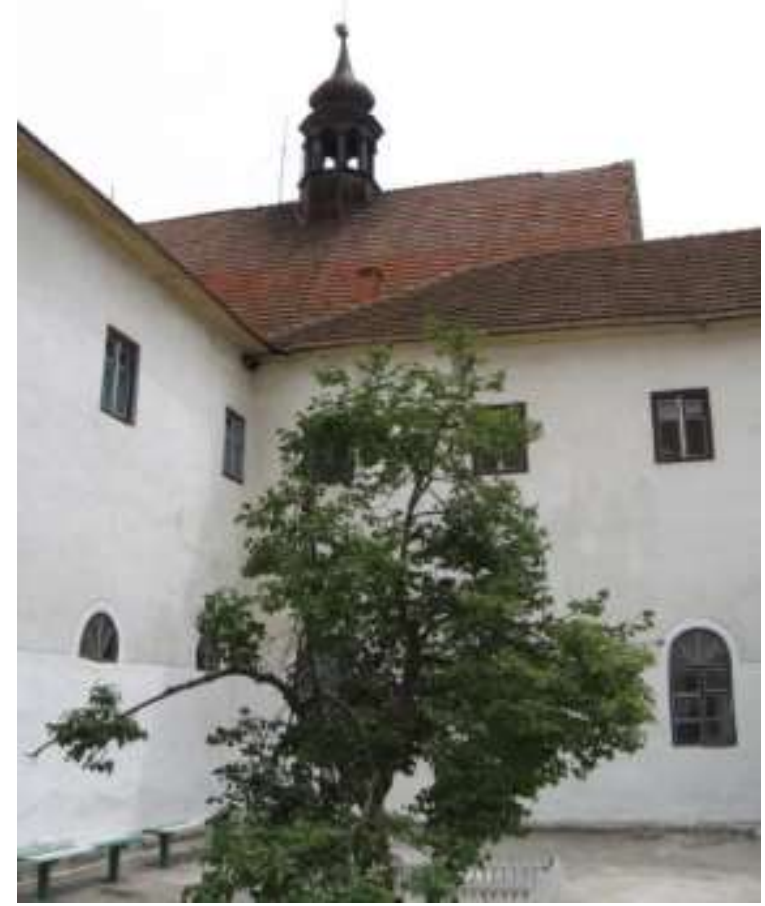

Рис. 12. Дворик монастиря. Фото автора 2012 р.

Під час перенесення до храму мощей Пратулинських Мучиників за участю багатьох священиків та при великому здвигу вірних, 17 червня 2007 р., а згодом 13 червня 2010 р. під час перенесення мощей св. Антонія Падевського 3 візитаціями перебував владика тернопільсько-зборівської єпархії Василій Семенюк. Отож в храмі зберігаються фрагменти мощей одного з Пратулинських Мучеників та Антонія Падевського.

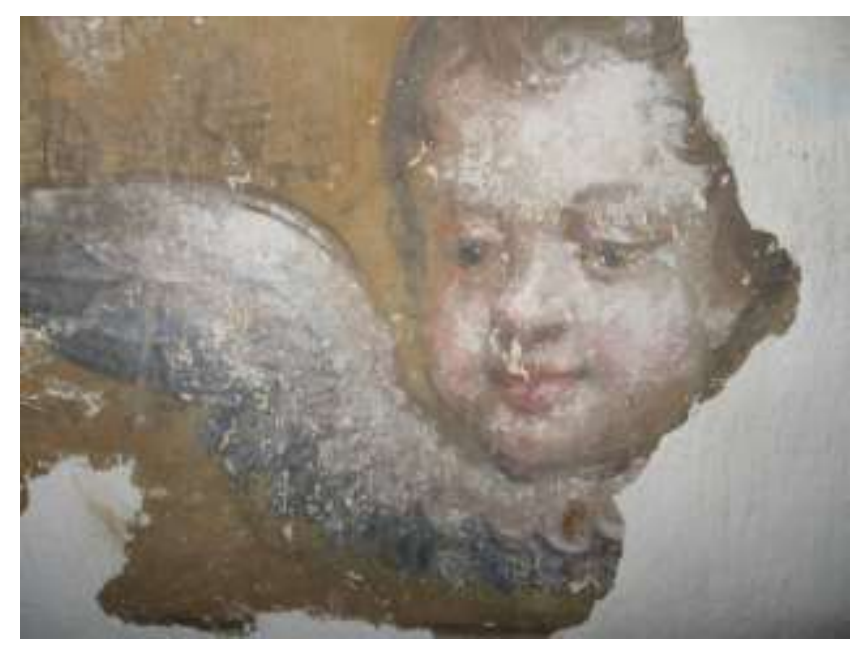

Рис. 13. Фрески з інтереру храму, знахідка архітектора Миколи Гайди. Фото 2010 p.

При парафії до закриття виховної колонії діяла парафіальна художня школа по виготовленню ікон та малої сакральної скульптури. Парафія співпрацювала також 3 профтеучилищем та школою виховної колонії. В 2012 р. двоє вихованців колонії 
охрестилися в греко-католицькому обряді. На території парафії збереглася кам'яна фігура св. Франциска. Цікаво, що в церкві Мучеників Пратулинських в 2007 р. побував Президент України Віктор Ющенко, що допоміг при відновленні храму, виділивши деревину на перекриття покрівлі.

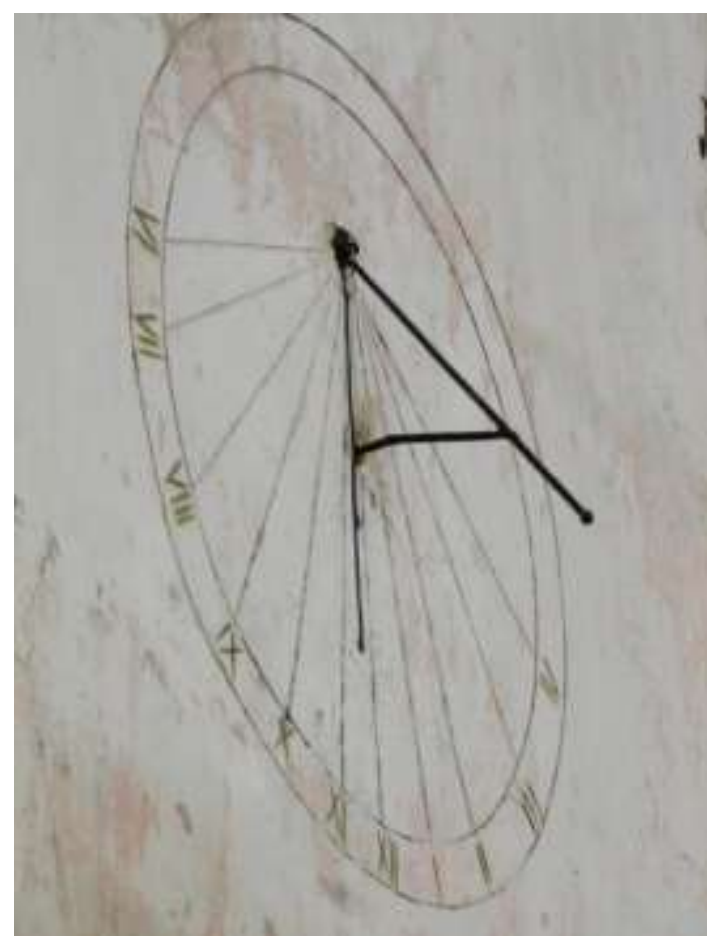

Рис. 14. Сонячний годинник кіния XVII cm. на південній стіні храму.

Фото автора 2008 p.
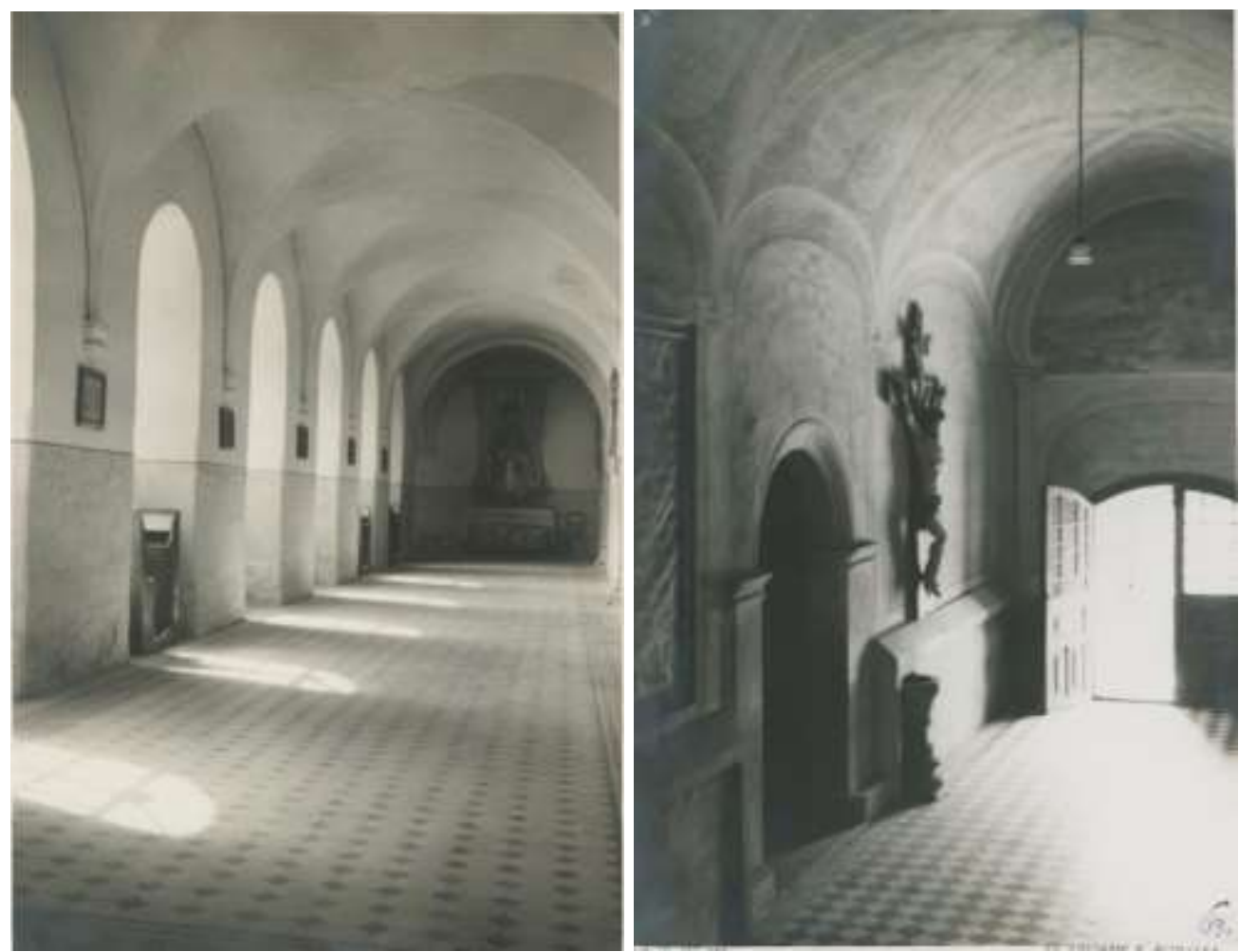

Рис. 15. Коридор келій монастиря. В Від до храму. 


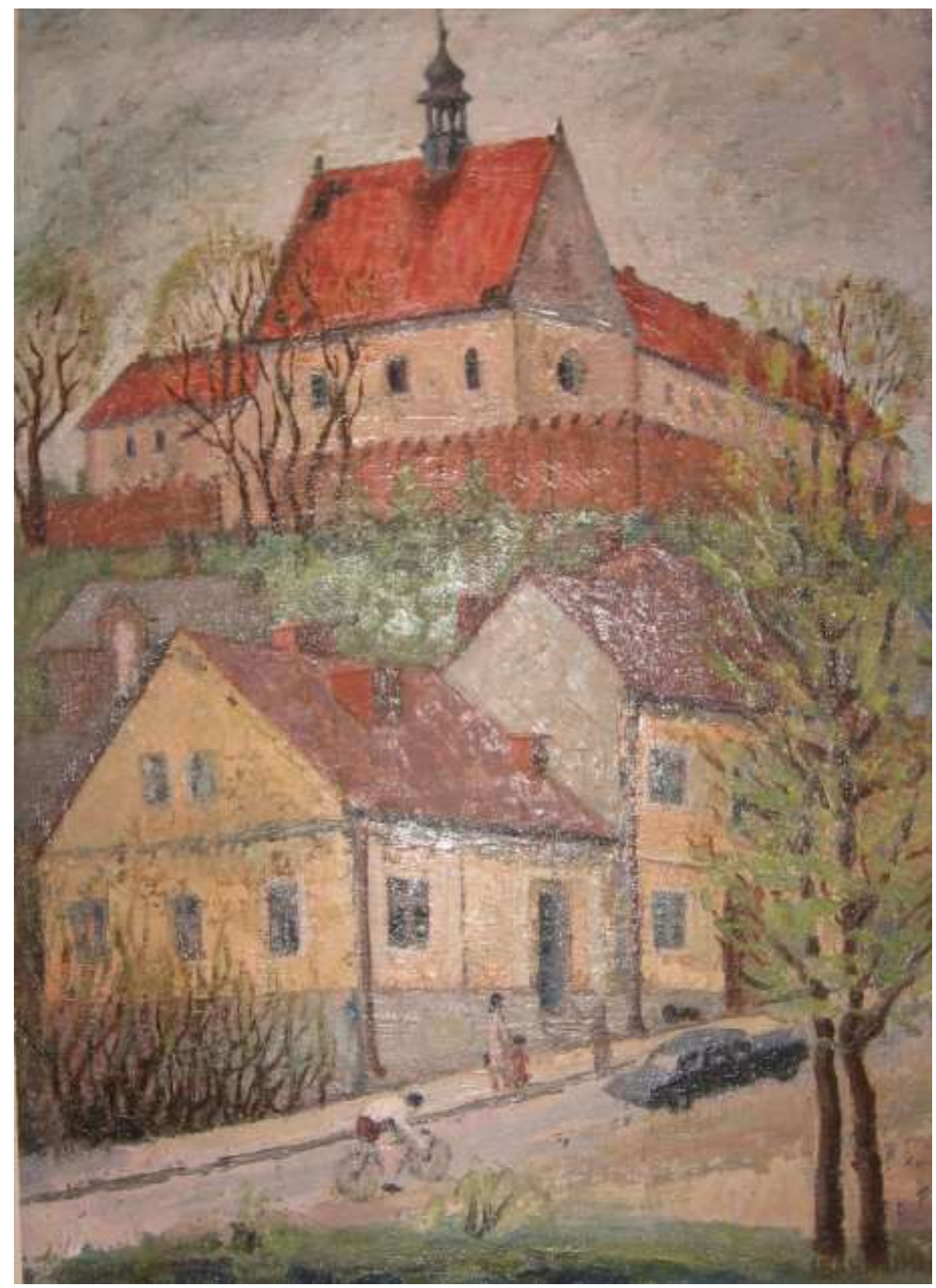

Рис. 16. Вид на монастир оо. Бернардинів. Мал. Василя Іванишина.

Фото автора, 2019 .

В приміщенні зліва від захрестія храму в навчальній художній майстерні церкви Мучеників Пратулинський зберігаються старовинні ікони в різьблених дерев'яних оправах. Ці витвори мистецтва знаходяться в жалюгідному стані, а рами роз'їдає шашель. Все ж автору вдалося індинтифікувати походження ікон пророчого ряду. Це роботи поч. XVIII ст. маляра-ігумена о. Теодозія Січинського, художника Павла Килимовича, його помічника Павла та сницаря Гната Стобинського $з$ Деревачівського монастиря, що пізніше (після пожежі в Красній Пущі) в 1912 р. заходами та сприянням митрополита Андрея Шептицького подаровані до нової мурованої церкви Краснопущанського монастиря оо. Василіан. 

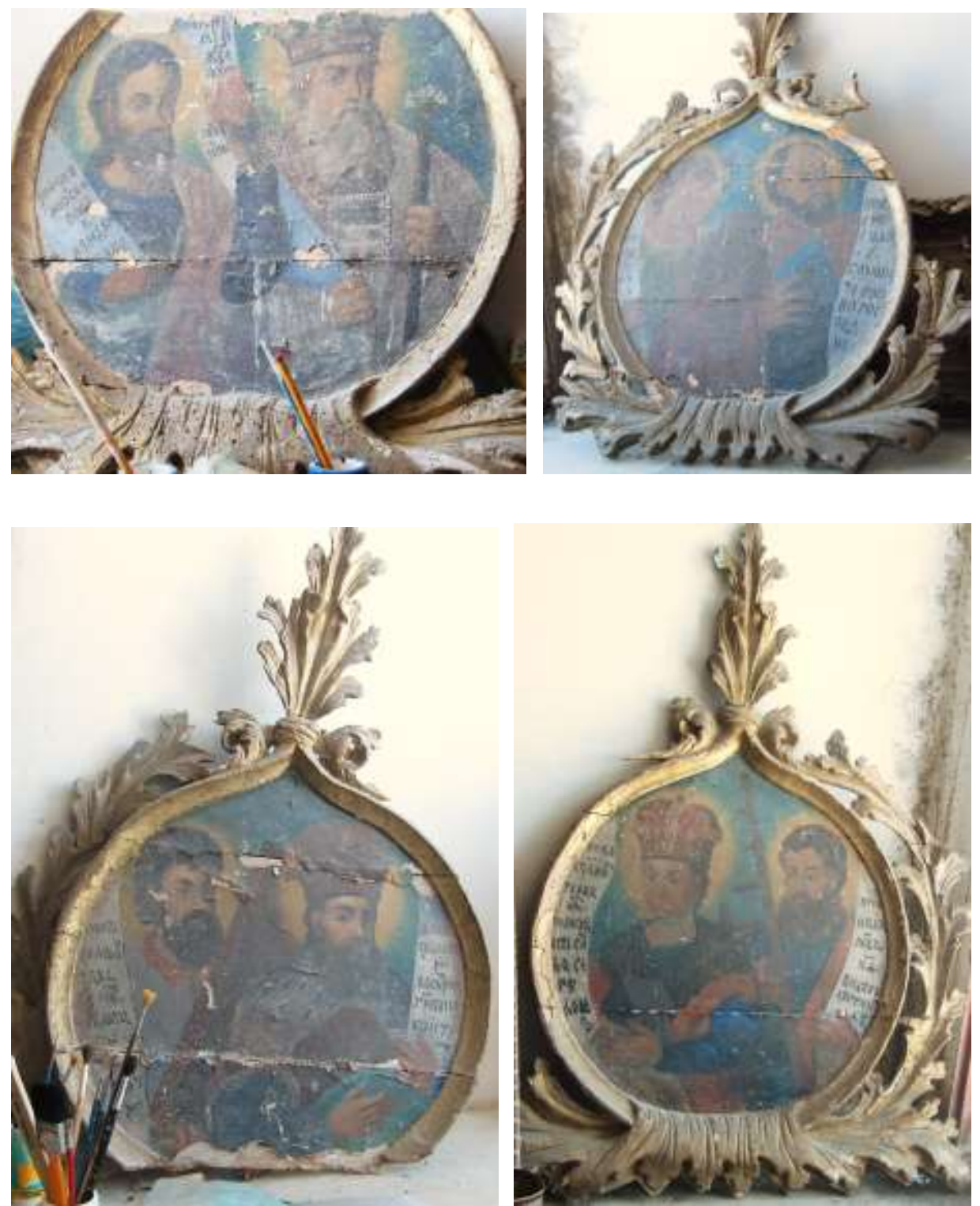

Рис. 17. Складові частини ряду пророків Краснопущанського іконостасу

о. Теодозія Січинського. Фото автора, 2016 р.

\section{Висновки}

Монастирський комплекс оо. Бернардинів у даний час пустує, але перебуває у користуванні Департаменту виконання покарань МВС України. Дана пам'ятка $є$ цікавим прикладом оборонної архітектури пізнього ренесансу.

\section{Використана література та джерела:}

Maciszewski, M., 1911. Brzeżany w czasach Rzeczypospolitej potskiej. Brody.

Ostrowski, J., ed., 2007. Koscioly i klasztory rzymskokatolickie dawnego wojewodstwa ruskiego. Materialy do dziejow sztuki sakralnej na ziemiach wschodnich dawnej Rzeczypospolitej. T.15. Krakow.

Fürstenhoff, J. G. M. von, 1755. Sammlung von Festungsplänen. II. Planes von Italien, Ungarn, Pohlen und denen Nordischen Königreichen.

Wojewodstwo Tarnopotskie, 1931. Tarnopoł.

Stejnr, A., 1934. O podziemiach kosciolow o cerkwach i cmentarzach miasta Brztzan. Glos Brzezanski, 7, s.3. Brzezany. 
Бев3, М., 2000. Обгрунт та визначення меж територій та охоронних зон для історикоархітектурного заповідника у м. Бережани, Т 1. Львів.

Слободян, В., 2004. Храми Рогатинщзини. Львів.

\section{References:}

Bevz, M., 2000. Substantiation and definition of boundaries of territories and protection zones for the historical and architectural reserve in Berezhany, T 1. L'viv.

Slobodyan, V., 2004. Temples of Rohatyn Region. L'viv.

Bohdan Tykhyy

Researcher,

State Historical and Architectural Reserve in Berezhany

email: t.dan@ukr.net

ORCID: 0000-0003-3793-1004

\section{DEFENSIVE CHURCH OF SAINT NICHOLAS AND THE MONASTERY OF BERNARDINS IN BEREZHANY}

(C) Tykhyy B., 2020.

Abstract: the article is devoted to the history of the monastery of the Order of Bernardines in Berezhany in Ternopil region. The analysis of the architectural features of the complex is main purpose of the work. The monastery is located in the northwest corner of the city. The territory of the was surrounded by defensive bastion fortifications. The monastery fortifications were a part of the city defensive lines. The mountain, on which the monastery located, is called - "St. Nicholas Mountain". On the place of the present monastery was a boyar's manor in the XIV century, and then the orthodox church of St. Nicholas.The construction of a defensive complex of monastic buildings began in 1630. The Bernardine complex includes - the Catholic Church of St. Nicholas, the house of the monastery cells, defensive walls and ramparts. The complex occupied the highest position in the north-western wing of the city's defense system. It was an important strategic point that controlled the Lviv-Berezhany road. The construction of all the objects of the monastery lasted 112 years until 1742.In 1809-1812, the Austrian authorities liquidated the city's powerful defenses. In particular, the ramparts and bastions that were on the territory of the monastery were eliminated. Today there is only a fragment of a defensive wall and a moat on the southern slope of the mountain, which separated the territory of the monastery from the urban areas of the New Town. The fortifications of the monastery are shown on the map of 1720 by Major Johann von Fürstenhof.

The bastion belt of the monastery had underground structures. In 2010, murals were found in the interior of the church. According to the author, the carved stone decoration of the church (columns, capitals) was made by the sculptor Johann Pfister (in 1630-1642). The altars, with carved figures of saints, were probably made by the artist Georg Ioan Pinzel from Buchach. The architecture of the monastery's defensive structures needs further research.

In the temple there are several valuable icons of the prophetic series of iconostasis. These are works originating from the famous Krasnopushchany iconostasis by Gnat Stobynsky and Fr. Theodosius of Sichynskyi. This iconostasis was donated in 1912 by Metropolitan Andrei Sheptytskyi. Restoration work on the monastery began in 2007 after 
a visit by President Victor Yushchenko. First of all, the roof of the temple was repaired. Work is underway to restore and recreate the interior of the temple. Archaeological research of lost fortifications needs special attention.

Keywords: Church of St. Nicholas, OO. Bernardine monastery, defense system, the city of Berezhany, Seniawski family. 